\title{
THE RELATIONSHIP BETWEEN PRODUCT DIVERSITY AND THE PERFORMANCE OF CREDIT UNIONS AND BADAN USAHA KREDIT PEDESAAN IN YOGYAKARTA SPECIAL PROVINCE
}

\author{
Stephanus Eri Kusuma \\ Universitas Gadjah Mada \\ (stephanuserikusuma@gmail.com) \\ Wihana Kirana Jaya \\ Universitas Gadjah Mada \\ (wihana@ugm.ac.id)
}

\begin{abstract}
This study analyzes the relationship between product diversity and the performance of microfinance institutions (MFIs), especially Credit Unions (CUs) and Badan Usaha Kredit Pedesaan (BUKPs) in Yogyakarta. It employs a binary logistic regression method in its analysis and utilizes annual pooled cross section data from 16 CUs and 34 BUKPs in Yogyakarta from 2011. The result indicated that there was a direct negative relationship between the levels of saving-loan product diversity and the scale of outreach and also between the levels of savingloan product diversity and depth of outreach. It also suggested an indirect negative relationship between the levels of saving-loan product diversity and staff productivity and also between the levels of saving-loan product diversity and self-sufficiency.
\end{abstract}

Keywords: product diversity, performance, microfinance institutions, CUs, BUKPs

\section{INTRODUCTION}

A shift of the paradigm and practice in the microfinance field in the last 10 years is the change in MFIs focus, from providing only a single product to offering combined microfinance products (Rossel-Cambier, 2008). ${ }^{1}$ Despite its increasingly widespread practice, the issue of combined microfinancing has received relatively little attention. The Rossel-Cambier's study stated that specific research questions such as whether combining credit and insurance services improved or weakened the organisational performance of micro-finance schemes remains underexplored.

Some previous empirical studies ${ }^{2}$ which focused on explaining the relationship between

\footnotetext{
${ }^{1}$ Initially, MFIs only provided business loan service. Nowadays, they also provide loans and savings for many purposes, insurance, transfer, leasing and non-financial services.

2 Esho, et al. (2005), Goddard, et al. (2008), Barry and Tacneng (2009), Rossel-Cambier (2010a, 2010b, 2011) and also Lensink, et al. (2011).
}

product diversity, diversification and the performance of MFIs indicated that there was still no consensus regarding the relationship between product diversity and the performance of MFIs. Despite our best efforts to find empirical studies related to this study, the authors could not find a study focused on the product diversity issue in the context of Indonesian MFIs. To fill this gap, the authors performed a study which focused on analyzing the relationship between product diversity and the performance of MFIs operating in Indonesia, especially in the context of Credit Unions (CUs) and the Badan Usaha Kredit Pedesaan (BUKPs) in Yogyakarta Special Province.

Yogyakarta was chosen as the region for this research because it is one of the regions in Indonesia with very dynamic microenterprises, which create a largermicrofinancing network (see Pradiptyo, et al., 2013). Thus, it can be predicted that the microfinance sector in Yogyakarta is very open to development and needs more discussion. In addition, December 2010 to Decem- 
Table 1. Some performance indicators of CU and BUKP in Yogyakarta Special Province, 2011

\begin{tabular}{lcc}
\hline \multicolumn{1}{c}{ Indicators } & CU & BUKP \\
\hline Number of units & 44 & 75 \\
Value of savings (in billion Rp.) & 69.94 & 84.21 \\
Value of loans outstanding (in billion Rp.) & 69.43 & 100.56 \\
Total assets (in billion Rp.) & 97.77 & 135.01 \\
Savings per units (in million Rp.) & 1.59 & 1.12 \\
Loans outstanding per unit (in million Rp.) & 1.58 & 1.34 \\
Total assets per unit (in million Rp.) & 2.22 & 1.80 \\
\hline
\end{tabular}

Source: Primary data from Income and Financial Management Department of Yogyakarta Special Province and Regional Credit Union Coordinating Agency of Yogyakarta Special Province (Puskopdit Bekatigade and Puskopdit Jatra Miguna), processed by the authors.

ber 2011 was used in this research as the data period because it is the most up-to-date overall annual data that can be provided by the MFIs sampled at the time of data gathering (September-December 2012).

The purpose of this research was to identify whether or not the relationship between product diversity and performance exists in the operation of the CUs and BUKPs in Yogyakarta Special Province. The CUs and BUKPs were chosen as the MFIs to be sampled with respect to certain considerations. First, the CUs and BUKPs were the two most sustainable examples of non-bank MFIs amongst the group of financial cooperatives and village credit institutions (ProFi, 2006; Rahayani, 2009). Second, empirical studies which focused on credit unions and village credit institutions (including BUKPs) were still limited (Kusumajati, 2012). Third, the probability of accessing reliable and actual data from the CUs and BUKPs was relatively higher than from the other non-bank MFIs because most of the CUs and BUKPs have a structured and relatively upto-date performance documentation system. Fourth, the individual CUs and BUKPs tend to have relatively similar main operational activities, operational scales and effectiveness levels of the institutional system. This gives a logical reasoning for integrating the unit data from the two different MFIs. ${ }^{3}$

\footnotetext{
${ }^{3}$ In regards to the operational activities of CUs and BUKPs, both MFIs have the same mission to serve people who are underserved or unserved by the existing financial institutions. In addition, both MFIs also place the provision of savings and credit services as their major activities. Regarding their scales of operation, the data showed that
}

The following section reviews the framework to understand the relationship between the product diversity and performance of the MFIs. The next section describes the methodology of this research. After that we explain the data and analysis of this study. The final section is the conclusion and recommendations.

\section{Relationship between the Product Diversity and Performance of MFIs}

Rossel-Cambier (2010b) stated that the provision of combined microfinancing, by definition, offered clients the possibility of a larger choice of financial services than that offered by mono-product MFIs. Offering more services means that more needs are addressed and hence more socially excluded people will make use of these services. According to Frankiewicz \& Churchil (2011), conceptually, product diversity and diversification can bring both positive and negative effects to an MFIs performance. The positive effects arise from the increase in client satisfaction and loyalty that will be translated into the increase in word of mouth promotion by clients and loans-savings clients transactions quality. In addition, the more varied products provided by the MFIs enable them to diversify

the average value of savings, credit and assets of the CUs and BUKPs in Yogyakarta Special Province is not very different (see table 1). Moreover, although the ownership and organization structure of these two MFIs are different, they have their own advantages regarding their institutional structured elements (e.g. formal and informal rules, monitoring and enforcement mechanisms) so that the effectiveness of their institutional systems are relatively similar. 
their sources and use of funding, and hence increase the effectiveness of their MFIs risk management. Those effects jointly generate an increase in the outreach and financial performance of MFIs. Meanwhile, the negative impacts arise from the financial and reputation loss risks, staff performance decreases because of over capacity, product canibalization or exclusion of the poor because of the inappropriate design that potentially exists when a new product is launched.

Rossel-Cambier (2010a), according to some studies, stated that combined microfinancing will support the achievement of economies of scope, the effectiveness of loan delivery and the decrease of transaction costs. It can also facilitate joint-client registration, the access to information about clients (for example through more direct contact from a more frequent transaction or saving transaction record) and access to a wider market. However, the Rossel-Cambier's study stated that the provision of combined microfinancing may increase the complexity of the operation of MFIs when excess transactions happen. In addition, a study by Lensink et al. (2011) stated that the provision of multiple products by MFIs, which combined financial and non financial services (named microfinance plus), was expected to: 1) solve multidimensional problems of poverty and be a tool to reach the poorest, 2) improve the human capital and loyalty of MFIs customers, 3 ) reduce the default risk hence the sustainability of MFIs and 4) build the comparative advantage of MFIs. But, microfinance plus can produce some unexpected impacts, such as: 1) higher operational costs, 2) an administrative burden, 3) poor quality or irrelevant services, 4) complex reporting and 5) low monitoring quality. The conceptual framework described above is illustrated in Figure 1 below.

Some empirical studies analyzed the relationship between the diversity and performance of MFIs. Even so, there was no consensus regarding such a relationship. The study by Esho et al. (2005) indicated that an increase of the feebased activity of CUs in Australia increased the financial risk and decreased the profitability of the observed CUs. The study by Goddard et al. (2008) found that the increase of fee-based activity in the operation of CUs in the United States was negatively related to the achievement of a risk-adjusted ROA of sampled CUs. The study by Barry \& Tacneng (2009) found that MFIs which focused on loan delivery had a higher level of depth of outreach but a lower

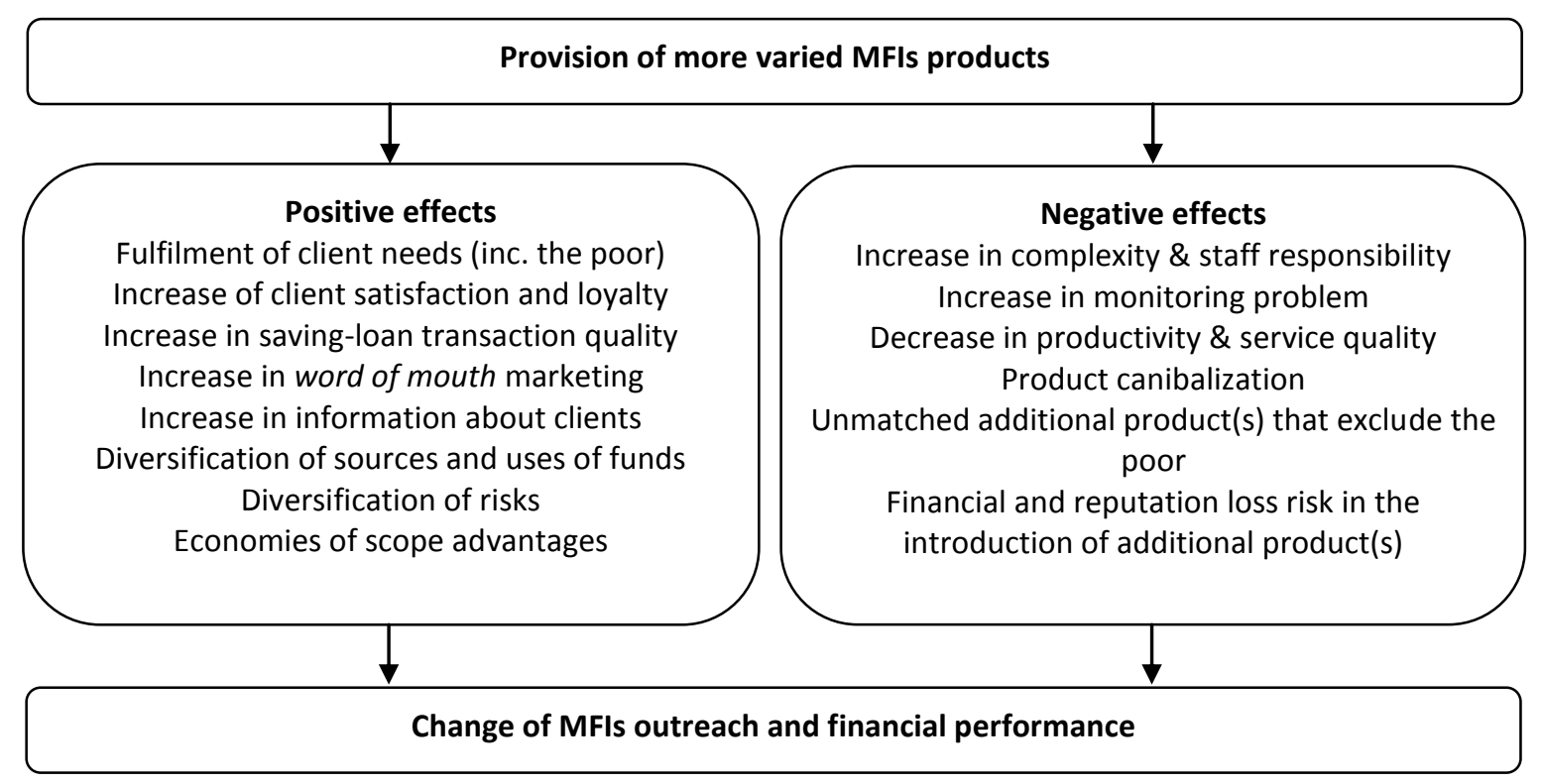

Source: Rossel-Cambier (2010a, 2010b), Lensink et al. (2011), Frankiewicz \& Churchil (2011), synthesized and figured by the authors.

Figure 1. Relationship between the product diversity and performance of MFIs 
scale of outreach, financial performance and portfolio quality in comparison with MFIs that were not only focused on loan delivery. Barry \& Tacneng's study also indicated that MFIs that provide non loan-saving products, especially for education and health services, tended to have a higher scale of outreach, productivity and portfolio quality but this accompanied a lower selfsufficiency in comparison with the MFIs that did not provide education and health services. The study of Rossel-Cambier (2010a) found that the provision of combined microfinance was positively related to the efficiency and productivity of MFIs, while the study by Rossel-Cambier (2010b) found that combined microfinance was positively related to the scale of outreach, but negatively related to the depth of outreach, of MFIs in Latin America and the Carribean. A case study conducted by Rossel-Cambier (2011) in Credit Union City of Bridgetown Barbados found that the introduction of new products restricted the access of poor clients as the attributes (procedures and costs) needed to access the new products did not match poor clients capacities. The study of Lensink, et al. (2011) which involved 290 rated MFIs in 61 countries indicated that MFIs which jointly provide financial and non financial services, named microfinance plus, tended to have a higher level of depth of outreach but a lower portfolio quality. In addition, the provision of social services in the microfinance plus scheme tended to have negative effects on the financial performance of the sampled MFIs.

\section{METHODOLOGY}

Referring to Barry \& Tacneng (2009), the authors built a model to test the relationship between the product diversity and performance of MFIs. The authors accomodated some additional variables that could potentially influence the performance of the MFIs which were recommended by Arsyad (2005), Okumu (2007) and Nyamsogoro (2010). In general, the performance model used in this study can be written as:

$$
Y=\alpha+\beta_{1} X_{1}+\beta_{2} X_{2}+\cdots+\beta_{n} X_{n}+\widehat{e}
$$

where $Y$ is the dependent variable that represents MFI performance; $X_{1}, X_{2}, \ldots, X_{n}$ are the independent variables that represent some factors potentially influencing the MFIs' performance; $\beta_{1}, \beta_{2}, \ldots, \beta_{n}$ are the estimated parameters for the independent variables used in the regression model, and $\widehat{e}$ is the error term. Specifically, the model can be written as:

$$
\begin{aligned}
& D K L I E N=\alpha+\beta_{1} \text { SIMPIN }+\beta_{2} \text { NONSIMPIN }+\beta_{3} A S E T+\beta_{4} \text { USIA }+\beta_{5} \text { SHRPINJ }+ \\
& \text { SHRSIMP }+\beta_{7} D W I L+\beta_{8} R A P I N J+\widehat{e} \ldots(\text { Model } 1) \\
& \text { DRAPINJ }=\alpha+\beta_{1} \text { SIMPIN }+\beta_{2} \text { NONSIMPIN }+\beta_{3} \text { ASET }+\beta_{4} \text { USIA }+\beta_{5} \text { SHRPINJ }+ \\
& \beta_{6} \text { SHRSIMP }+\beta_{7} \text { DWIL }+\beta_{8} \text { KLIEN }+\widehat{e} \ldots \text { (Model 2) } \\
& D P R O D=\alpha+\beta_{1} \text { SIMPIN }+\beta_{2} \text { NONSIMPIN }+\beta_{3} \text { ASET }+\beta_{4} \text { USIA }+\beta_{5} \text { SHRPINJ }+ \\
& \left.\beta_{6} \text { SHRSIMP }+\beta_{7} D W I L+\beta_{8} \text { KLIEN }+\beta_{9} \text { RAPINJ }+\widehat{e} \ldots \text { (Model } 3\right) \\
& D R B O=\alpha+\beta_{1} S I M P I N+\beta_{2} N O N S I M P I N+\beta_{3} A S E T+\beta_{4} U S I A+\beta_{5} S H R P I N J+ \\
& \left.\beta_{6} \text { SHRSIMP }+\beta_{7} D W I L+\beta_{8} \text { KLIEN }+\beta_{9} \text { RAPINJ }+\widehat{e} \ldots \text { (Model } 4\right) \\
& \text { DOSS }=\alpha+\beta_{1} \text { SIMPIN }+\beta_{2} \text { NONSIMPIN }+\beta_{3} \text { ASET }+\beta_{4} \text { USIA }+\beta_{5} \text { SHRPINJ }+ \\
& \left.\beta_{6} \text { SHRSIMP }+\beta_{7} D W I L+\beta_{8} \text { KLIEN }+\beta_{9} \text { RAPINJ }+\widehat{e} \ldots \text { (Model } 5\right)
\end{aligned}
$$


Performance variables: 1) Scale of outreach (dummy of MFI active clients or DKLIEN); 2) depth of outreach (dummy of MFI loans disbursed per client or DRAPINJ) in which the bigger the value of loans disbursed per client means a lower depth of outreach as the MFI then is focused on relatively bigger scale (wealthier) loan clients; 3) staff productivity (dummy of loans disbursed per staff or DPROD), 4) operational efficiency (dummy of operational cost per average asset based on periods or DRBO), 5) selfsufficiency (dummy of operational self-sufficiency or DOSS).

Product diversity variables: 1) The level of loans-savings product diversity (the number of loans-savings product types or SIMPIN); 2) the level of non loans-savings product diversity (the number of non loans-savings product types or NONSIMPIN)

Control variables: 1) Size of the MFIs (assets or ASET); 2) duration of MFI's operation (age of MFI or USIA); 3) proportion of loans outstanding (loans to assets ratio or SHRPINJ); 4) proportion of savings (savings to assets ratio or SHRSIMP); 5) operational area of MFI service unit (dummy of location — urban or village - or DWIL(1)).

This study employed a binary logistic regression method, a model regression in which the dependent variable is a dichotomous variable. Following Goldberger, as cited in Maddala (1983), who suggested that the use of binomial or binary choice models could overcome the inefficient parameter estimation with ordinary least squares when the datasets were not normally distributed, as in the case of the datasets available for this study. The binary regression method uses a discrete dependent variable and assumes that individuals are faced with a choice between two alternatives and that their choice depends on their characteristics. As all performance indicators in our datasets were continous variables, we converted them into dichotomous variables by dividing the value of each performance indicator (for example: the number of clients) into two: the one with a value above the average value of population or relatively high was coded as ' 1 ', and the one with a value below or exactly same as the average value of population or relatively low was coded as ' 0 '.

There are some limitations that should be considered related to the models used in this study. First, the models used in this study may have suffered from an endogeinity problem. Regarding the endogeinity issue in an econometric model, according to Wooldridge (2012), an econometric model suffers from endogeinity problems if at least one of the "explanatory variables" is endogenous or jointly determined with the dependent variable (In other words, the assumption of a zero covariance is violated). This problem may arise as a consequence of the exclusion of explanatory variable(s) from the models, called omitted variable(s). In our model formation, we excluded a variable, named institutions. Institutions are a set of formal and informal rules and also its enforcement mechanism that determines individual and organizational behavior (Burky \& Perry, 1998). In the context of the MFIs operation, it is actualized in: 1) government or MFIs' regulations (formal rules) and 2) social conventions, culture, social norms, and ethics (informal rules) which are involved in the MFIs operations (Kusumajati, 2012). Based on our observations of the sampled MFIs used in our study, institutions were reflected in the formal rules (governor's decrees, various government documents, supervisor guidance, written organizational policy and convention, various kinds of standard operating procedures, planning documents), informal rules (organizational culture and ethics, client culture), enforcement mechanisms (reporting and monitoring procedures/techniques, incentives and sanction mechanisms) adopted by each sampled MFI.

Some prominent Indonesian empirical microfinance studies that focused on the effects of institutions on MFIs' performance in Indonesia confirmed that institutions significantly influence MFIs' performance. ${ }^{4}$ Even so, it was diffi-

\footnotetext{
${ }^{4}$ A study by Martowijoyo (2001) found that implementation of the Indonesian Rural Credit Banks System (Bank Prkreditan Rakyat System) influenced the performance of the Rural Finance Institutions that were supposed to be Rural Credit Banks. A study by Arsyad (2005) found that formal rules, informal rules, the
} 
cult for us to find any quantitave proxy that was considered appropiate to represent the institutions variable. Initially, we considered the type of MFIs to be used in this study as the proxy of institutions. Unfortunately, our field observations found that the institutional features of each MFI did not provide clear-cut evidence. In this case, similar types of MFIs (for example within CUs) did not always have the same features of institutions and achieve institutional performance, while the different types of sampled MFIs (for example between CUs and BUKPs) did not always have different features of institutions or achieve institutional performance. Thus, we cannot hypothesize that the type of MFIs reflect the type of institutions. Finally, as we could not find an alternative proxy for institutions, we dropped the institutions variable from our quantitave models. Furthermore, our field observations recognized that institutions tended to be correlated with an MFI's size, age, operational area, loan proportion, and saving proportion. Specifically, the relatively large, old, urban-based MFIs in our sample tended to have better formal institutions and enforcement, while the smaller, younger, and rural-based MFIs tended to have poorer formal institutions and enforcement. In addition the rural-based MFIs we sampled tended to have better informal rules and enforcement in comparison to the urbanbased ones. This evidence means that a correlation does exist between the institutions variable (which was omitted from the models used in this study) and some explanatory variables (MFI size, age, and operational area). Thus, it potentially leads to endogeinity problems as the explanatory variables correlated with the omitted variable.

The second limitation of this study was the exclusion of macroeconomic variables in the models used. It was because there was no clear operation areas of the sampled MFIs. In this case, some sampled MFIs operated in villages or

interaction between formal and informal rules, and also the enforcement of formal and informal rules influenced Village Credit Institutions in Bali. A study by Kusumajati (2012) confirmed that formal rules and informal rules significantly affected the performance of Credit Unions in Indonesia. at the sub-district level where macroeconomic data was not available. Morever, some sampled MFIs operated in some dispersed sub-districts with different macroeconomic characteristics. In short, it would need an abundance of resources to provide convenient macroeconomic data for each MFI's operational area. The third limitation was the use of logistic probability models. This study utilized a binary logistic model. This model predicts less strongly the direct quantitative effect of independent variables in affecting performance as its dependent variables are binary choices.

\section{DATA AND ANALYSIS}

This research used quantitative and qualitative data for the analysis. The quantitive data were cross section data sourced from the annual operational performance statistical reports of each sampled MFI (CU and BUKP), while the qualitative one was gathered from a direct interview with each $\mathrm{CU}$ respondent (CU Manager and Head of the Office of each BUKPs), and the Manager of the Coordinating Body of the CUs and BUKPs in Yogyakarta Special Province. This research employed $16 \mathrm{CU}$ units (from a total of 36 units) and 34 BUKP units (from the total of 75 units) in Yogyakarta Special Province. This research utilized a multi-stage sampling process as explained in Figure 2.

Later, table 2 explains the basic descriptive statistics of the variables used in this study.

Regarding the five models proposed for the analysis, the results of the Omnibus test, Hosmer-Lomeshow test, classification table \& Cox-Snell $R^{2}$ and Nagelkerke $R^{2}$, there was sufficient statistical evidence to conclude that all five models were acceptable to explain the relationship between the product diversity and performance of the sampled MFIs (see table 3). From the statistical results, we found that the five models tended to pass all of the tolerance criteria or could be judged as 'fit' models. 


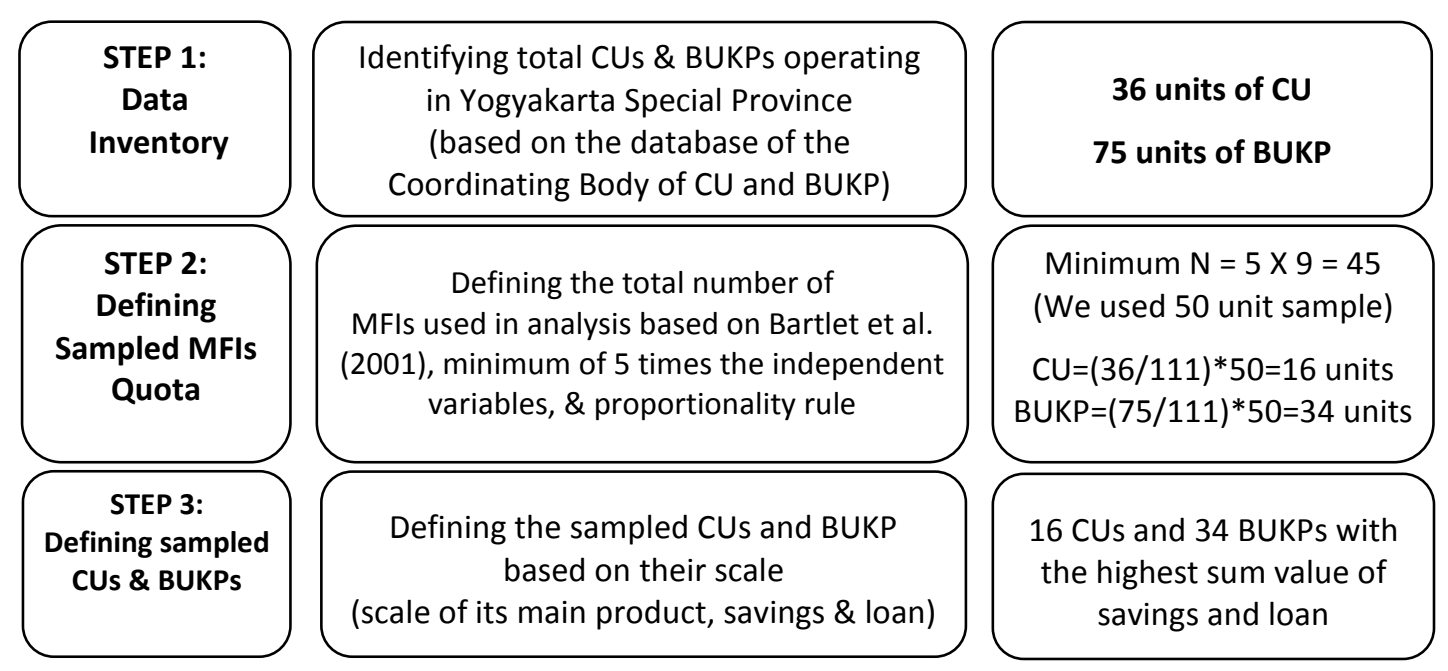

Note: The total number of $36 \mathrm{CUs}$ in the sampling process was the number of CU recommended by the Credit Union Coordinating Body of Yogyakarta. According to the monitoring staff of the body, among the 44 CUs in its database, there are 6 CUs which are in dispute (for 2 or 3 periods they have not reported their performance or are operationally inactive) and 2 CUs located outside Yogyakarta province. Thus, these 8 CUs were not recommended for this research. After consideration, this study excluded these 8 CUs from the CU sample basis.

Sources: Figured by the authors

Figure 2. Sampling process

Table 2. Descriptive statistics of variables used in this study

\begin{tabular}{lccccc}
\hline \multicolumn{1}{c}{ Indicator } & $\mathrm{N}$ & $\begin{array}{c}\text { Minimum } \\
\text { value }\end{array}$ & $\begin{array}{c}\text { Maximum } \\
\text { value }\end{array}$ & Average & $\begin{array}{c}\text { Standard } \\
\text { deviation }\end{array}$ \\
\hline KLIEN (people) & 50 & 156.00 & 2205.00 & 601.80 & 369.27 \\
RAPINJ (million Rp.) & 50 & 1.03 & 17.68 & 5.44 & 2.76 \\
PROD (million Rp./staff) & 50 & 114.94 & 1553.60 & 566.17 & 315.98 \\
RBO (\%) & 50 & 2.97 & 18.62 & 9.79 & 3.08 \\
OSS (\%) & 50 & 94.19 & 222.90 & 136.20 & 23.32 \\
SIMPIN (product type) & 50 & 3.00 & 13.00 & 5.28 & 2.38 \\
NONSIMPIN (product type) & 50 & 0.00 & 5.00 & 1.66 & 1.47 \\
ASET (billion Rp.) & 50 & 1.54 & 11.71 & 3.25 & 1.90 \\
USIA (years) & 50 & 2.00 & 31.00 & 17.26 & 6.53 \\
SHRPINJ (\%) & 50 & 43.95 & 92.88 & 71.97 & 12.20 \\
SHRSIMP (\%) & 50 & 12.27 & 95.52 & 63.43 & 16.18 \\
DWIL (urban-1 / rural-0) & 50 & 0.00 & 1.00 & 0.56 & 0.50 \\
\hline
\end{tabular}

Sources: Primary data from sample units of CU and BUKP, processed by the authors

Table 3. The result of logistic regression

\begin{tabular}{|c|c|c|c|c|c|}
\hline \multirow{2}{*}{$\begin{array}{l}\text { Independent } \\
\text { Variable }\end{array}$} & \multicolumn{5}{|c|}{ Model (Dependent Variable) } \\
\hline & $\begin{array}{c}\text { Model } 1 \\
\text { (DKLIEN) }\end{array}$ & $\begin{array}{c}\text { Model } 2 \\
\text { (DRAPINJ) }\end{array}$ & $\begin{array}{l}\text { Model } 3 \\
\text { (DPROD) }\end{array}$ & $\begin{array}{l}\text { Model } 4 \\
(\mathrm{DRBO})\end{array}$ & $\begin{array}{l}\text { Model } 5 \\
(\mathrm{DOSS})\end{array}$ \\
\hline SIMPIN & $\begin{array}{c}\mathbf{- 1 . 0 7 5 *} \\
(0.091)\end{array}$ & $\begin{array}{c}\mathbf{- 2 . 2 2 4 * *} \\
(0.033)\end{array}$ & $\begin{array}{l}\mathbf{- 0 . 5 4 4} \\
(0.132)\end{array}$ & $\begin{array}{l}\mathbf{- 3 . 6 4 8} \\
(0.111)\end{array}$ & $\begin{array}{c}\mathbf{- 0 . 3 5 3} \\
(0.230)\end{array}$ \\
\hline NONSIMPIN & $\begin{array}{c}0.353 \\
(0.589)\end{array}$ & $\begin{array}{c}0.489 \\
(0.476)\end{array}$ & $\begin{array}{c}0.480 \\
(0.390)\end{array}$ & $\begin{array}{c}0.622 \\
(0.488)\end{array}$ & $\begin{array}{c}0.607 \\
(0.194)\end{array}$ \\
\hline ASET & $\begin{array}{c}3.578 * * * \\
(0.009)\end{array}$ & $\begin{array}{l}3.393^{*} \\
(0.007)\end{array}$ & $\begin{array}{l}-0.900 \\
(0.150)\end{array}$ & $\begin{array}{l}-4.720 * \\
(0.067)\end{array}$ & $\begin{array}{c}-1.469^{* *} \\
(0.010)\end{array}$ \\
\hline USIA & $\begin{array}{c}0.106 \\
(0.408)\end{array}$ & $\begin{array}{c}0.201 \\
(0.277)\end{array}$ & $\begin{array}{c}0.109 \\
(0.417)\end{array}$ & $\begin{array}{l}-0.358 \\
(0.274)\end{array}$ & $\begin{array}{c}0.089 \\
(0.408)\end{array}$ \\
\hline
\end{tabular}


Table 3. The result of logistic regression (continued)

\begin{tabular}{|c|c|c|c|c|c|}
\hline \multirow[b]{2}{*}{ Independent Variable } & \multicolumn{5}{|c|}{ Model (Dependent Variable) } \\
\hline & $\begin{array}{c}\text { Model } 1 \\
(\mathrm{DKLIEN})\end{array}$ & $\begin{array}{c}\text { Model } 2 \\
\text { (DRAPINJ) }\end{array}$ & $\begin{array}{l}\text { Model } 3 \\
\text { (DPROD) }\end{array}$ & $\begin{array}{l}\text { Model } 4 \\
(\mathrm{DRBO})\end{array}$ & $\begin{array}{l}\text { Model } 5 \\
(\text { DOSS) }\end{array}$ \\
\hline SHRPINJ & $\begin{array}{c}0.115 \\
(0.162)\end{array}$ & $\begin{array}{c}0.084 \\
(0.224)\end{array}$ & $\begin{array}{c}0.092 \\
(0.164)\end{array}$ & $\begin{array}{c}0.174 \\
(0.173)\end{array}$ & $\begin{array}{c}-0.077 * \\
(0.091)\end{array}$ \\
\hline SHRSIMP & $\begin{array}{l}-0.001 \\
(0.962)\end{array}$ & $\begin{array}{c}0.020 \\
(0.697)\end{array}$ & $\begin{array}{l}0.124 * \\
(0.034)\end{array}$ & $\begin{array}{l}0.410 * \\
(0.053)\end{array}$ & $\begin{array}{l}-0.038 \\
(0.225)\end{array}$ \\
\hline DWIL(1) & $\begin{array}{c}1.033 \\
(0.333)\end{array}$ & $\begin{array}{c}1.071 \\
(0.329)\end{array}$ & $\begin{array}{c}-2.583 * * \\
(0.013)\end{array}$ & $\begin{array}{l}-6.153 * \\
(0.093)\end{array}$ & $\begin{array}{c}-1.676^{*} \\
(0.062)\end{array}$ \\
\hline KLIEN & & $\begin{array}{c}-0.014 * * * \\
(0.004)\end{array}$ & $\begin{array}{c}0.007 * * \\
(0.016)\end{array}$ & $\begin{array}{c}-0.001 \\
(0.886)\end{array}$ & $\begin{array}{l}0.006 * \\
(0.017)\end{array}$ \\
\hline RAPINJ & $\begin{array}{l}-1.283 * \\
(0.010)\end{array}$ & & $\begin{array}{c}0.334 \\
(0.133)\end{array}$ & $\begin{array}{c}0.824 \\
(0.161)\end{array}$ & $\begin{array}{l}0.341 * \\
(0.083)\end{array}$ \\
\hline $\mathrm{C}$ & $\begin{array}{c}-10.994 \\
(0.165)\end{array}$ & $\begin{array}{l}-5.014 \\
(0.577)\end{array}$ & $\begin{array}{c}-17.079 \\
(0.056)\end{array}$ & $\begin{array}{l}-6.130 \\
(0.631)\end{array}$ & $\begin{array}{c}7.034 \\
(0.218)\end{array}$ \\
\hline Observation & 50 & 50 & 50 & 50 & 50 \\
\hline$X^{2}$ Omnibus & $\begin{array}{c}31.473 * * * \\
(0.000)\end{array}$ & $\begin{array}{c}32.692 * * * \\
(0.000)\end{array}$ & $\begin{array}{c}28.598 * * * \\
(0.001)\end{array}$ & $\begin{array}{c}46.297 * * * \\
(0.000)\end{array}$ & $\begin{array}{c}22.766^{* * * *} \\
(0.007)\end{array}$ \\
\hline $\begin{array}{c}X^{2} \text { Hosmer \& Lemeshow } \\
(\mathrm{H}-\mathrm{L})\end{array}$ & $\begin{array}{c}4.422 \\
(0.817)\end{array}$ & $\begin{array}{c}9.550 \\
(0.298)\end{array}$ & $\begin{array}{c}14.096 \\
(0.079)^{*}\end{array}$ & $\begin{array}{c}2.062 \\
(0,979)\end{array}$ & $\begin{array}{l}10.031 \\
(0.263)\end{array}$ \\
\hline Classification Table (\%) & 82 & 92 & 86 & 84 & 76 \\
\hline Cox \& Snell $R^{2}$ & 0.467 & 0,480 & 0.436 & 0.604 & 0.366 \\
\hline Nagelkerke $R^{2}$ & 0.631 & 0,658 & 0.586 & 0.806 & 0.490 \\
\hline
\end{tabular}

Note:

1) $*, * *, * * *$ means that the null hypothesis is rejected at the significance error $(\alpha)$ of $10 \%, 5 \%$, and $1 \%$. This study allows a significance error up to $10 \%$ to minimize the risk of rejecting the true alternative hypothesis because this study is a social research involving peoples' behavior and institution effects that potentially limit the sensitivity of proxies used in the quantitative analysis.

2) Omnibus value, H-L value, and classification table value indicate the fitness of the model, while Cox \& Snell $R^{2}$ and Nagalgerke $R^{2}$ indicate the relationship intensity between overall independent variables and the dependent variable. This study set the tolerance value at $5 \%$ for the first two test, $70 \%$ for the third test, and $30 \%$ (moderate) for the fourth fitness model test.

3) Number in brackets is the p-value.

Sources: Primary data from sample units of CU and BUKP, processed by the authors

The following part of this section analyzes the relationship between the product diversity and the performance of the sampled MFIs. This study classified the analysis into two parts, one related to product diversity in terms of loanssavings (in which loans and savings are the main products of the sampled CUs and BUKPs) and the other related to the product diversity in terms of non loans-savings products. Figure 3 below summarizes the relationship between the variables used in the analysis in this study.

Regarding the relationship between savingloan product diversity and performance, the re- sult of the regression indicated a significant direct relationship between the level of savingloan product diversity and outreach performance indicators, both of scale and depth of outreach. Statistical analysis indicated that additional types of saving-loan products provided by the sampled MFIs decreased the probability of the MFIs achieving a higher-level number of loan clients (higher-level scale of outreach) and increased the probability of the sampled MFIs achieving a lower-level average loan size (a higher-level depth of outreach). This was indicated by the negative coefficient and $p$-value of SIMPIN that was lower than $10 \%$ in model 1 and model 2 . 
However, the relationship between saving-loan product diversity and other performance aspects such as staff productivity, operational efficiency and operating self-sufficiency was not statistically significant, as indicated by the p-value of SIMPIN which was higher than $10 \%$ in models 3,4 and 5 (see table 4). Furthermore, the regression results do not find any statistically significant relationship between the level of non saving-loan product diversity and all five performance indicators used in this study (see table 4).

The direct negative relationship between the level of saving-loan product diversity and scale of outreach (the number of loan clients) predicts that the MFIs with more varied saving-loan product types tend to have a smaller probability of reaching a higher number of loan clients. Probably, this happened because the MFIs with more diversed saving-loan products were challenged by having more complex operations (e.g. product administration, infrastructure provision, promotion and reporting). This reduced the resources, especially time and effort, that could be allocated by the MFI's staff to find and process potential clients. Thus, the more diversified the product was, the MFIs tended to have a lower number of clients.

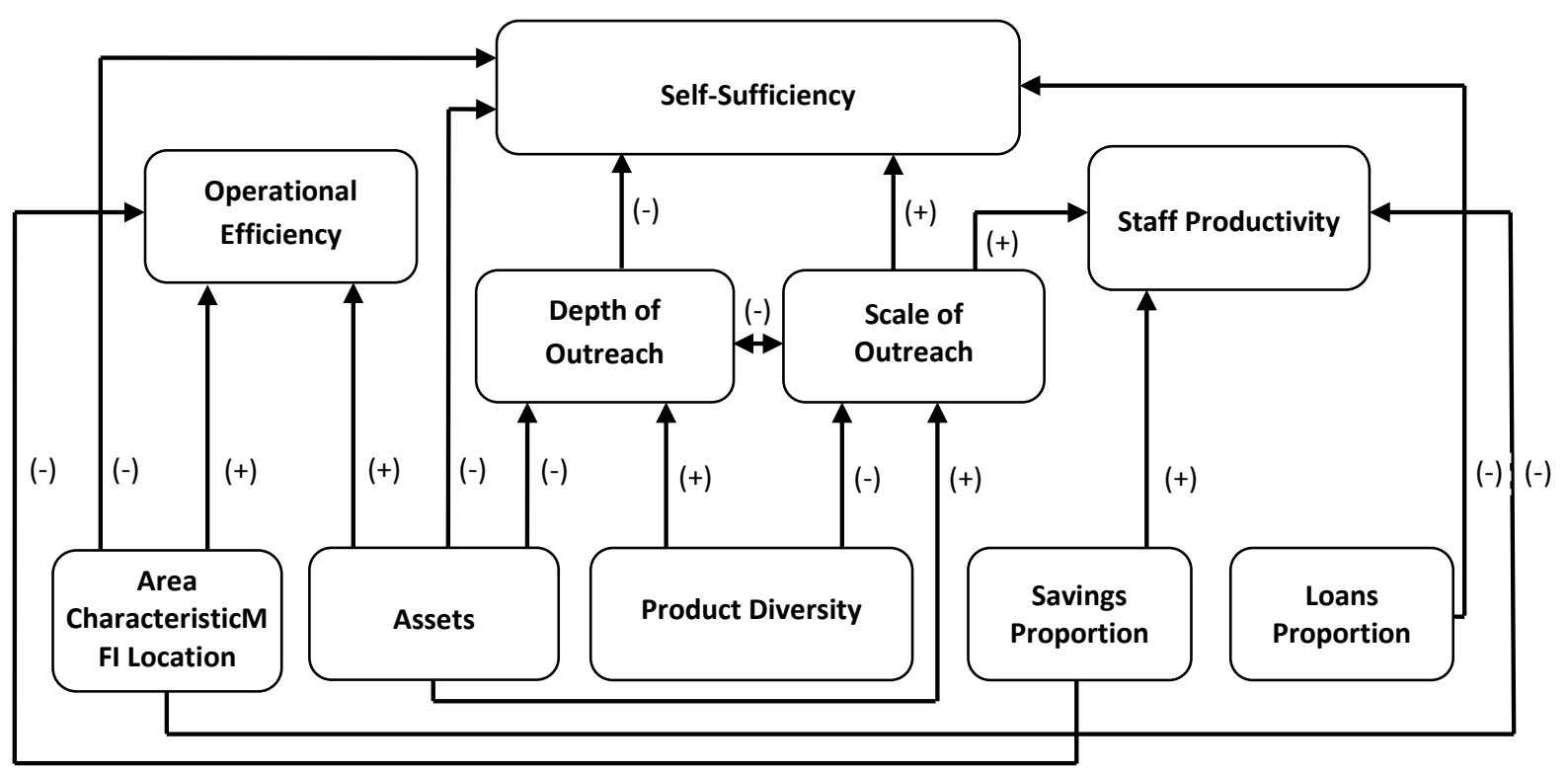

Sources: Figured by the authors

Figure 3. The relationship between variables in the models based on the results of logistic regression analysis

Table 4. The result of logistic regression (product diversification variables)

\begin{tabular}{|c|c|c|c|c|c|}
\hline \multirow{2}{*}{$\begin{array}{l}\text { Independent } \\
\text { Variable }\end{array}$} & \multicolumn{5}{|c|}{ Model (Dependent Variable) } \\
\hline & $\begin{array}{c}\text { Model } 1 \\
\text { (DKLIEN) }\end{array}$ & $\begin{array}{c}\text { Model } 2 \\
\text { (DRAPINJ) }\end{array}$ & $\begin{array}{c}\text { Model } 3 \\
\text { (DPROD) }\end{array}$ & $\begin{array}{l}\text { Model } 4 \\
\text { (DRBO) }\end{array}$ & $\begin{array}{l}\text { Model } 5 \\
\text { (DOSS) }\end{array}$ \\
\hline SIMPIN & $\begin{array}{c}-1.075^{*} \\
(0.091)\end{array}$ & $\begin{array}{c}-2.224 * * \\
(0.033)\end{array}$ & $\begin{array}{l}-0.544 \\
(0.132)\end{array}$ & $\begin{array}{l}-3.648 \\
(0.111)\end{array}$ & $\begin{array}{l}-0.353 \\
(0.230)\end{array}$ \\
\hline NONSIMPIN & $\begin{array}{c}0.353 \\
(0.589)\end{array}$ & $\begin{array}{c}0.489 \\
(0.476)\end{array}$ & $\begin{array}{c}0.480 \\
(0.390)\end{array}$ & $\begin{array}{c}0.622 \\
(0.488)\end{array}$ & $\begin{array}{c}0.607 \\
(0.194)\end{array}$ \\
\hline
\end{tabular}

Note: $*, * * * *$ means that the null hypothesis is rejected at the significance error $(\alpha)$ of $10 \%, 5 \%$, and $1 \%$.

Sources: Primary data from sample units of CU and BUKP, processed by the authors 
Table 5. The result of logistic regression (product diversity and outreach variables)

\begin{tabular}{cccccc}
\hline \multirow{2}{*}{$\begin{array}{c}\text { Independent } \\
\text { Variable }\end{array}$} & $\begin{array}{c}\text { Model 1 } \\
\text { (DKLIEN) }\end{array}$ & $\begin{array}{c}\text { Model 2 } \\
\text { (DRAPINJ) }\end{array}$ & $\begin{array}{c}\text { Model 3 } \\
\text { (DPROD) }\end{array}$ & $\begin{array}{c}\text { Model 4 } \\
\text { (DRBO) }\end{array}$ & $\begin{array}{c}\text { Model 5 } \\
(\text { DOSS) }\end{array}$ \\
\cline { 2 - 5 } SIMPIN & $-1.075^{*}$ & $-2.224^{*} *$ & -0.544 & -3.648 & -0.353 \\
& $(0.091)$ & $(0.033)$ & $(0.132)$ & $(0.111)$ & $(0.230)$ \\
NONSIMPIN & 0.353 & 0.489 & 0.480 & 0.622 & 0.607 \\
& $(0.589)$ & $(0.476)$ & $(0.390)$ & $(0.488)$ & $(0.194)$ \\
KLIEN & $(0.333)$ & $(0.329)$ & $(0.013)$ & $(0.093)$ & $(0.062)$ \\
& & $-0.014 * * *$ & $0.007 * *$ & -0.001 & $0.006 *$ \\
RAPINJ & $(0.004)$ & $(0.016)$ & $(0.886)$ & $(0.017)$ \\
& $-1.283 *$ & & 0.334 & 0.824 & $0.341 *$ \\
\hline
\end{tabular}

Note: $* * *, * * *$ means that the null hypothesis is rejected at the significance error $(\alpha)$ of $10 \%, 5 \%$, and $1 \%$. Sources: Primary data from sample units of CU and BUKP, processed by the authors

Meanwhile, the direct negative relationship between the level of saving-loan product diversity and average loans disbursed per client means that MFIs with more varied saving-loan products had a higher probability of servicing more clients with relatively small size loans. In other words, MFIs with more diverse savingloan products had a higher probability of being more focused on clients with relatively small size loans (which is often correlated with less wealthy clients) and/or attract more clients looking for small size loans who would deal with the MFIs. ${ }^{5}$

The result of the regression also suggested the existence of an indirect negative relationship between the level of saving-loan product diversity and two financial performance indicators, especially staff productivity and operational selfsufficiency. Regarding the indirect negative relationship between the level of saving-loan product diversity and staff productivity (the value of loans disbursed per staff), the relationship was mediated by the scale of outreach (the number of loan clients). Related to the result, in

\footnotetext{
${ }^{5}$ Average loan size or average outstanding loan per client can be used as the proxy of depth of outreach (see Ledgerwood, 1999:225; Martowijoyo, 2001:128,159; Weiss \& Montgomerry, 2005:43; UNCDF, 2006:2). The wealthier clients are not interested in smaller loans (UNCDF, 2006). In addition, the wealthier clients tend to have a greater probability of accessing larger loans as they have greater assets and the capacity to provide conventional collateral in comparison with less wealthy clients.
}

the previous discussion, the analysis predicted the existence of a negative relationship between the level of saving-loan product diversity and the number of clients. In addition, the regression results also indicated a positive relationship between the number of clients and staff productivity. According to the statistical result, there is a positive coefficient of KLIEN and a $p$-value lower than 5\% in model 3 (see table 5). It means that the decrease of the number of clients tended to decrease the probability of the sampled MFIs achieving a higher level of staff productivity in generating loans. The result meant that a higher level of saving-loan product diversity tended to be followed by a decrease in the probability of achieving a higher number of clients and, in the longer term, the probability of achieving a higher-level of staff productivity to generate loans.

Regarding the indirect negative relationship between the level of saving-loan product diversity and self-sufficiency (operational self-sufficiency), this relationship was mediated by the scale of outreach (the number of loan clients) and the depth of outreach (indicated by the value of loans disbursed per client). The previous discussion explained the existence of a negative relationship between the level of saving-loan product diversity and the number of loan clients and also the value of loans disbursed per client. In addition, the regression analysis also indicated a statistically significant and positive relation- 
ship between the number of clients as well as the average loans disbursed and operational selfsufficiency, indicated by a positive coefficient of KLIEN and a $p$-value lower than 5\% in Model 5 (see table 5). It means that the negative relationship between the level of saving-loan product diversity and the number of loan clients and the value of loans disbursed per client, in the longer term, tends to lead to a lower probability of the MFIs achieving self-sufficiency.

The result of the logistic regression also indicated a direct relationship between some control variables (especially assets, proportion of loans outstanding, proportion of savings, the operational area of MFI unit) and some indicators of performance.

Assets, as the proxy of MFI size, tend to have a direct relationship with almost all of the performance indicators, especially a positive relationship with the scale of outreach and operational efficiency and a negative relationship with the depth of outreach and operational selfsufficiency. It indicates that, although the bigger sized MFIs tend to have a higher probabilty of being efficient and reach more clients than the smaller sized MFIs, they have a higher probability of focusing on wealthier clients (lower depth of outreach) and achieve lower-levels of selfsufficiency because of their inability to minimize production costs. This was indicated by each ASET coefficient value sign and their $p$-value being lower than 105 (see Table 6, especially ASET in model 1, 2, 4,and 5).

Loans proportion, as the proxy of the resources allocation to the most important productive investment of the MFIs, tended to have a direct negative relationship with operational selfsufficiency (as indicated by a negative coefficient and a $9.1 \%$ p-value of SHRPINJ in model $5)$. It means that the increase of loans proportion tends to increase the probability of the sampled MFIs achieving a lower self-sufficiency. This evidence indicates that, practically, too much investment in loan assets is not always good for the sampled MFIs because it is probably positively correlated with the problem of over capacity, potential default, and higher operational costs. Thus, it seems a necessity for the sampled MFIs to consider a moderate loan investment in their operations.

Savings proportion had a positive relationship with the probability of the sampled MFIs achieving staff productivity and a negative relationship with the probability of the sampled MFIs achieving higher-levels of operational efficiency. The statistical analysis showed that an increased saving proportion tended to increase the probability of the sampled MFIs achieving a higher staff productivity to generate loans (indicated by a positive coefficient of SHRSIMP in model 3 and a $p$-value lower than 5\%). The reasons behind this evidence are probably: 1)

Table 6. The result of logistic regression (other independent variables)

\begin{tabular}{cccccc}
\hline \multirow{2}{*}{$\begin{array}{c}\text { Independent } \\
\text { Variable }\end{array}$} & $\begin{array}{c}\text { Model 1 } \\
\text { (DKLIEN) }\end{array}$ & $\begin{array}{c}\text { Model 2 } \\
\text { (DRAPINJ) }\end{array}$ & $\begin{array}{c}\text { Model 3 } \\
\text { (DPROD) }\end{array}$ & $\begin{array}{c}\text { Model 4 } \\
\text { (DRBO) }\end{array}$ & $\begin{array}{c}\text { Model 5 } \\
(\text { DOSS) }\end{array}$ \\
\cline { 2 - 6 } & $3.578^{*} *$ & $3.393^{*}$ & -0.900 & $-4.720^{*}$ & $-1.469^{* *}$ \\
ASET & $(0.009)$ & $(0.007)$ & $(0.150)$ & $(0.067)$ & $(0.010)$ \\
& 0.106 & 0.201 & 0.109 & -0.358 & 0.089 \\
USIA & $(0.408)$ & $(0.277)$ & $(0.417)$ & $(0.274)$ & $(0.408)$ \\
SHRPINJ & 0.115 & 0.084 & 0.092 & 0.174 & $-0.077^{*}$ \\
& $(0.162)$ & $(0.224)$ & $(0.164)$ & $(0.173)$ & $(0.091)$ \\
SHRSIMP & -0.001 & 0.020 & $0.124 *$ & $0.410^{*}$ & -0.038 \\
& $(0.962)$ & $(0.697)$ & $(0.034)$ & $(0.053)$ & $(0.225)$ \\
DWIL(1) & 1.033 & 1.071 & $-2.583 * *$ & $-6.153 *$ & $-1.676^{*}$ \\
& $(0.333)$ & $(0.329)$ & $(0.013)$ & $(0.093)$ & $(0.062)$ \\
\hline
\end{tabular}

Sources: Primary data from sample units of CU and BUKP, processed by the authors 
savings products may facilitate the MFIs to access the information about loan applicants (including their character), 2) savings products may provide collateral substitution for loan applicants who do not have enough conventional collateral (land certificates or vehicle ownership documents), and 3) savings products tend to increase the source of money to be lent by the MFIs. However, in the case of the sampled MFIs, the results of the regression showed a positive coefficient of SHRSIMP in model 4 and a $p$-value lower than $10 \%$. It meant that an increase in the savings proportion tended to decrease the probability of the sampled MFIs achieving lower operational costs (higher efficiency). There is a tendency that a higher proportion of savings tends to increase the cost of operating which is translated into a decrease in efficiency (see table 6 above).

The result of the regression also confirmed that the MFIs located in urban areas had a higher probability of accessing lower operational costs and of being more efficient than the ones located in rural areas. This was reflected by the negative coefficient (-6.153) and significant $p$-value $(9,3 \%)$ of variable DWIL in model 4 (see Table 6). Even so, the MFIs located in urban areas tend to have a lower probability of achieving a higher-level of staff productivity in generating loans and a higher-level of sufficiency than the ones located in rural areas. This was reflected by the negative coefficient $(-2.583$ and -1.676$)$ and significant $p$-value $(1,3 \%$ and $6,2 \%)$ of variable DWIL in model 3 and model 5 (see Table 6). It seems that MFIs in urban areas tend to meet higher levels of competition which reduces their productivity and ability to generate higher profits in comparison with MFIs located in rural areas. It translates into the lower self-sufficiency achieved by urban MFIs.

\section{CONCLUSION AND RECOMMENDATION}

The purpose of the research was to identify whether the relationship between productivity and performance existed in the operation of the CUs and BUKPs in Yogyakarta Special Province. The analysis confirmed a significant direct relationship between the levels of saving-loan product diversity and outreach performance indicators, both for scale and depth of outreach. However, that was not the case for the other performance aspects such as staff productivity, operational efficiency and operating self-sufficiency. In addition, the analysis also indicated indirect negative relationships between the levels of saving-loan product diversity and staff productivity to generate loans and self-sufficiency. However, the analysis does not confirm a significant relationship between the level of non saving-loan product diversity and all five performance indicators.

Based on the analysis, we recommend a diversification strategy which can be applied in the operations of the sampled MFIs. For the MFIs that focus on building a good financial performance and reaching large number of clients, according to the model and analysis of this studies, it is suggested that they do not have too many saving-loan products if trying to increase their performance. Meanwhile, for the MFIs that focus on serving the low income and low-scale transaction clients, and have some degree of tolerance in achieving a superior financial performance, providing more varied saving-loan products would be a good strategy to increase their performance. In addition, this study had some limitiations. It is recommended that these limitations should be considered in any further related research. The limitations include: 1) the limited number of types and their operational areas, 2) the absence of dynamic analysis, 3) the use of imperfect indicators as this study only used a single indicator for each variable used in the model, 4) the absence of performance indicators based on clients and 5) the measurement of the level of product diversity that did not consider the transaction volume of each product. In addition, it would benefit further related research if it would accomodate a quantitative endogeinity analysis and include the institutions variable in the model(s) used.

\section{REFERENCES}

Arsyad, Lincolin, 2005. An assesment of performance and sustainability of microfinance institutions: A case study of village credit 
institutions of Gianyar, Bali, Indonesia. Unpublished $\mathrm{PhD}$ Thesis, Flinders University, Adelaide.

Barry, T. \& R. Tacneng, 2009. Governance, performance and diversification: Evidence from African microfinance institutions. Paper presented at Southwestern Finance Association 2010 Annual Meeting: Corporate Governance. Retrieved from http:// southwesternfinance.org/conf-2010/F33.pdf on July 19, 2012.

Bartlett, James E., Joe W. Kotrlik, \& Chadwick C. Higgins, 2001. "Organizational research: Determining appropriate sample size in survey research". Information Technology, Learning, and Performance Journal, 19(1):43-50.

Burky, S.J. \& G.E. Perry, 1998. Beyond the Washington Consensus: Institution Matter. Washington, D.C., USA: The World Bank.

Esho, Neil, Paul Kofman, \& Ian G. Sharpe, 2005. "Diversification, Fee Income and Credit Union Risk". Journal of Financial Services Research, 27(3): 259-281.

Frankiewicz, Cheryl \& Craig Churchill, 2011. Making Microfinance Work: Managing Product Diversification. Turin, Italy: International Training Centre of The ILO.

Goddard, John, Donal McKillop, \& John O.S. Wilson, 2008. "The diversification and financial performance of US credit unions". Journal of Banking and Finance, 32: 18361849 (doi:10.1016/j.jbankfin.2007.12.015).

Kusumajati, Titus Odong, 2012. Faktor ekonomi dan kelembagaan dalam keberlanjutan credit union di Indonesia. Unpublished $\mathrm{PhD}$ Thesis, Gadjah Mada University, Yogyakarta.

Ledgerwood, Joanna, 1999. Microfinance Handbook: An Institutional and Financial Perspective. Washington, D.C., USA: The World Bank.

Lensink, Robert, Roy Mersland, \& Vu Thi Hong Nhung, 2011. Should microfinance institutions specialize in financial services? Paper presented at 4th International Research Workshop on Microfinance, November 2425, 2011. Retrieved from http://www.rug. $\mathrm{nl} /$ research/globalisation-studiesgroningen/research/conferencesandseminars /conferences/eumicrofinconf2011/papers/10 b.lensink-mersland-vu.doc on August 18, 2012.

Maddala, G. S., 1983. Limited-dependent and Qualitative Variables in Econometrics. Cambridge: Cambridge University Press.

Martowijoyo, Sumantoro, 2001. Dampak pemberlakuan sistem bank perkreditan rakyat terhadap kinerja lembaga keuangan pedesaan. Unpublished $\mathrm{PhD}$ Thesis, Gadjah Mada University, Yogyakarta.

Nyamsogoro, Ganka Daniel, 2010. Financial sustainability of rural microfinance institutions (MFIs) in Tanzania. Unpublished $\mathrm{PhD}$ Thesis, University of Greenwich, Greenwich. Retrieved from http://core.ac.uk/ download/pdf/316086.pdf on July 19, 2012.

Okumu, Luka Jovita, 2007. The microfinance industry in Uganda: Sustainability, outreach and regulation. Unpublished $\mathrm{PhD}$ Thesis, University of Stellenbosch, Stellenbosch. Retrieved from http://scholar. sun.ac.za/bitstream/handle/10019.1/1091/O kumu,\%20L.J.O.pdf.pdf?sequence=2\&isAll owed=y on July 19, 2012.

Pradiptyo, R, C. Sugiyanto, Sumiyana, I. N. Dwiputri, Y.H. Permana, ... A. Kurniawan, 2013. Optimal Network for BPD Regional Champion to Support Financial Inclusion (SEADI Discussion Paper No. 5). Retrieved from Support for Economic Analysis Development in Indonesia Project website http://www.seadiproject.com/0_repository/S EADI-13-

R113\%20Optimal\%20Bank\%20Network\%2 0for\%20Inclusiveness(1).pdf on November 8, 2014.

Promotion of Small Finance Institutions-ProFi, 2006. Update of the Microfinance Landscape in Indonesia. In Third Window MFI Study Final Report (pp.63-81). Jakarta: ProFi Jakarta. Retrieved from http://www. microfinancegateway.org/sites/default/files/ mfg-en-paper-regulation-supervisionsupport-of-non-bank-non-cooperativemicrofinance-institutions-jan-2006.pdf on July 20, 2012.

Rahayani, Zita Tesa, 2009. Analisis Kinerja Lembaga Keuangan Mikro Badan Usaha Kredit Perdesaan dan di Daerah Istimewa Yogyakarta. Unpublished Undergraduate Thesis. Gadjah Mada University, Yogyakarta. 
Rossel-Cambier, Koen, 2008. Combined microfinance: Selected research questions from a stakeholder point of view (CEB Working Paper No 08/004). Retrieved from http:// www.microfinancegateway.org/sites/default /files/mfg-en-paper-combined-microfinance-selected-research-questions-from-astakeholder-point-of-view-2008.pdf on March 28, 2013.

Rossel-Cambier, Koen, 2010a. Can combining credit with insurance or savings enhance the sustainability of microfinance institutions? (CEB Working Paper No. 10/057). Retrieved from https://dipot.ulb.ac.be/ dspace/bitstream/2013/70367/1/wp10057.pd fl on March 28, 2013.

Rossel-Cambier, Koen, 2010b. Do multiple financial services enhance the poverty outreach of microfinance institutions? (CEB Working Paper No. 10/058). Retrieved from www.rug.nl/research/events/workshopmicro finance 2010/pdfmicro/rossel-cambier.pdf on March 28, 2013.

Rossel-Cambier, Koen, 2011. Understanding the dynamics of product diversification on microfinance performance outcomes: A case study in Barbados (CEB Working Paper No. 11/008). Retrieved from https://dipot.ulb. ac.be:8443/dspace/bitstream/2013/78912/1/ wp11008.pdf on March 28, 2013.

The United Nations Capital Development Fund-UNCDF, 2006. Core performance indicators for microfinance. Retrieved from http://www.uncdf.org/en/node/2169 on July 19, 2012.

Weiss, John \& Heather Montgomery, 2004. Great expectations: microfinance and poverty reduction in Asia and Latin America (MPRA Paper No. 33142). Retrieved from http://mpra.ub.uni-muenchen.de/33142/ on July 18, 2012. 


\section{APPENDIX The General Description of Sampled MFIs Products}

The CUs and BUKPs observed in this study provide savings, loans and non saving-loan products. From our observations, generally we found that most of the CUs had a greater variety of products in comparison with the BUKPs. The process of product development between the CUs and BUKPs also differs. The products offered by each CU were determined by the management and board of directors (Pengurus) based on the approval of the annual members' meeting (Rapat Anggota Tahunan). Meanwhile, the products offered by each BUKP were determined by the Provincial Government through a Governor's decree. However, some BUKPs developed additional products which were not covered by the decree. Another difference between the CUs and BUKPs was the clients who could access the products. A CU only serves its members, while BUKPs serve anybody who wants to do business with them. In the next part, we will give a general description of their products.

The savings products provided by CUs can be grouped into five categories, which are: 1) demand deposits (Simpanan Bunga Harian), in which clients can save or withdraw their money anytime, 2) time deposits (Simpanan Sukarela Berjangka), in which clients can withdraw their money according to a maturity period, generally 1-12 months, 3) education savings (Simpanan Pendidikan) in which clients can withdraw their money according to their schooling period (for example: after the savers reach higher levels of education, or a certain educational level) and the maturity period ranges from 1-5 years, 4) pension savings (Simpanan hari Tua/Masa Depan), in which the savers can withdraw their money after reaching a certain age (generally about 50 years old) ${ }^{6}, 5$ ) capitalization savings (Simpanan kapitalisasi) which are provided to clients who want to build their assets, even if they do not have money to save (in this case the CU lends money to the member, at ' $\mathrm{x}$ ' \% loan interest rate, then the member must save all the loaned money in capitalization savings with a more than ' $x$ ' $\%$ interest rate) and 6) savings schemes that are not included in the five schemes above, such as land and building investment savings, special religion day savings and community savings. The saving interest rates offered by each sampled CU varied. They ranged between $2-10 \%$ for the demand deposits, $4-15 \%$ for the time deposits, $4-11.6 \%$ for educational savings and $8-14 \%$ percent for pension savings. Meanwhile, savings products provided by BUKP were limited to demand deposits (Simassa) which gave $4-6 \%$ interest rate and time deposits (deposito) which had a $8-12 \%$ interest rate. But, some BUKPs provided other saving schemes, such as rotating association savings (tabungan arisan), educational savings and childrens' savings schemes.

Regarding the loan products, the sampled CUs provided a wide array of loans. These can be classified into 5 main categories: 1) business loans, a loan to finance productive purposes, 2) consumption loans, a loan to finance consumption products purchases, such as vehicles, electronic equipment, houses and buildings (and their material or equipment), education and daily consumption product purchases, 3) capitalization loans, a loan to build the member's own assets, in which the borrower receives a loan from the $\mathrm{CU}$ and all of it is saved in a $\mathrm{CU}$ savings product, especially capitalization savings, 4) emergency loans, a loan to finance an urgent need (such as land / house / vehicle brokerage capital, marriage funding or medical treatment) and which will be paid back in a relatively short-term period and 5) other loans that are not included in the 4 loan classifications above (such as a partnership loan, a loan given to another financial institution to finance their business, or community loans, a loan given to a grassroots community to finance their business. The loan interest

\footnotetext{
${ }^{6}$ Some CUs established schemes where savers must save a certain amount of money every month until they reach the age at which they can withdraw their money.
} 
rate provided by the sampled $\mathrm{CU}$ varied, ranging from 10.8 to $48 \%$ annually. Business and consumption loans were offered by most of the sampled CUs with the rate being between 15 to $24 \%$ annually. Meanwhile, emergency loans tended to be the most expensive loans from a CU (excepting emergency loans for medical treatment) with interest rates being above $24 \%$ annually. Education loans and capitalization loans tended to be the cheaper loans with interest rates below $15 \%$. Regarding the loan products of the BUKPs, most of the sampled BUKPs offered the same products. They were common loans, a loan given for both productive or consumption purposes, and incidental loans, a loan to fund any emergency needs. BUKPs charged interest rates of 18-30\% anually for common loans and $30-36 \%$ anually for incidental loans.

For the non saving-loan products, almost all of the sampled CUs provided loan protection schemes for their members, some kind of solidarity fund (for example: solidarity funds for the death or sickness of members) and educational schemes. The CUs' loan protection is facilitated by Dana Perlindungan Masyarakat (Daperma). This is an institution which provides facilitation to members who die when they still have a loan to repay to a CU. This institution writes off the member's outstanding loan and gives a grant (santunan) to the member's family/surviving relatives. The members need not pay an insurance fee as this is paid by their CU. Regarding the solidarity fund, it can be provided either by Daperma or the CU internally. The solidarity fund provided by Daperma is a solidarity fund for members who die, while the CUs provide various ones, depending on each CU's policy and capacity. The loan protection and solidarity funds in the sampled CUs had a double role. Firstly, they gave protection to members and their families in case they were unable to repay their loans because of the death or sickness of the member. Secondly, they also reduce the credit risk burden of the CUs as the loan insurance scheme by Daperma covered any outstanding unpaid loans of dead members. In addition, the solidarity fund scheme is a real way for the CUs to show attention to the members difficult conditions. This builds up the members loyalty and stimulates the members not to try to cheat in their transactions with their CUs. Regarding the education facilities, there are two types of educational programme provided by the sampled CUs. The first one is a basic educational programme. It covers basic financial education, household management and a motivational programme. The second one is an advanced educational programme. It covers some form of business training given to members according to their business field. Educational activities in the sampled CUs were facilitated through seminars, workshops or visits to the community villages in the CU's operational area. Educational activities by the $\mathrm{CU}$ will help $\mathrm{CU}$ members to recognize and understand the spirit and operational activities of the $\mathrm{CU}$ so they can have positive feelings in their transactions with the CU. They can also help the members to manage their money and businesses more cleverly. For the non savings-loan BUKP products, we found that some BUKPs provided a loan protection facility to their clients. However, this differed from the loan protection facility offered by the CUs, in that the BUKP clients must pay the insurance fee. Some BUKPs also provide a payment center to pay telephone, electricity and water service bills. In addition, we did not find any structured educational activities provided by the BUKPs, excepting visits to and advice for their non-discipline loan clients. 